UNIVERSIDADE DA BEIRA INTERIOR

Ciências Sociais e Humanas

\title{
The role of collateral and relationship lending in loan pricing: evidence from United Kingdom SMEs
}

\author{
Fábio Dias Duarte \\ Dissertação para obtenção do Grau de Mestre em: \\ Economia \\ ( $2^{\circ}$ ciclo de estudos)
}

Supervisor: Prof. ${ }^{a}$ Doutora Ana Paula Matias Gama

Covilhã, Outubro de 2011 


\section{Master thesis additional credits}

2011 - Co-Author of the paper submitted and accepted for ISBE - INSTITUTION FOR SMALL BUSINESS AND ENTREPRENEURSHIP: “Determinants of explicit and implicit loan price: Empirical evidence from United Kingdom SMEs”

2011 - Co-Author of the paper submitted for 24TH AUSTRALIAN FINANCE AND BANKING CONFERENCE ( $1^{\text {st }}$ Submission): "The role of collateral and relationship lending.in loan pricing" (under review)

2011 - Co-Author of the paper submitted for MIDWEST FINANCE ASSOCIATION CONFERENCE $\left(1^{\text {st }}\right.$ Submission): “The role of collateral and relationship lending.in loan pricing Evidence from UK SMEs" (under review)

2011 - Co-Author of the paper submitted for SOUTHWESTERN FINANCE ASSOCIATION CONFERENCE $\left(1^{\text {st }}\right.$ Submission): "The role of collateral and relationship lending.in loan pricing Evidence from UK SMEs" (under review)

2011 - Co-Author of the paper submitted for JOURNAL OF BUSINESS RESEARCH: "The role of collateral in relationship lending. Evidence from UK SMEs" (under review) 


\section{Acknowledgements}

I would like to thank my supervisor Professor Ana Paula Matias Gama for accept guide and work with me since the first moment. Her orientation and inspiration was very important in the final result of this master thesis. Thanks for her trust.

I would like to thank to Helena for her advice and help in the initial step of this work. Their support turned out to be important in the literature research and in the consistence of the final output

Also, i would like to thank Mr Luís Marques Oliveira for his friendship which he always demonstrated in this difficult and long process. Thanks for his patience.

A word of gratefulness to my friends for their loyalty and source of courage. I would also dedicate this work especially to my friends Ângela Silva, Sara Fonseca, André Santos, Filipe Freches and José Canadas. Thanks for your support and friendship.

With my deeply love, i would like to thank and dedicate this master thesis to my mum, Maria José, my sister, Raquel, and my godmother, Paula. A special thanks for my girlfriend Susana. The success of this work is also dedicated to you and our family.

Finally I would dedicate my master thesis to my father, Jaime, which had no time to see the final result of this work. Wherever you are now, you stay always in our hearts and memories. 


\begin{abstract}
This study investigates how the use of collateral affects the incentives of borrowers, lenders and the relationship between them in loan pricing. Using the UK Survey of Small and Medium-Sized Enterprises 2008, the results from a simultaneous equation approach show that high quality borrowers choose a contract with more collateral and lower interest rate, suggesting that collateral acts as an incentive device to adverse selection problem in credit markets. By distinguish business and personal collateral the findings suggest that personal collateral seems to be more effective in acting as a sorting device in line with screening models. Regarding the nature borrower-lender relationship the results also show a substitution effect between relationship length and collateral requirements from the main bank. But the main bank uses explicit loan interest rate as a loss leader to secure long-term rents on relationship business, suggesting that inter-temporal shifting rents is possible.
\end{abstract}

Keywords: credit rationing, loan pricing, collateral, relationship lending, small and mediumsized enterprises (SMEs)

JEL classification: G20; G21 


\section{Resumo}

Este estudo analisa o impacto da concessão de garantias (collateral) e o tipo de relacionamento entre credor e mutuário na determinação da taxa de juro dos empréstimos contraídos. Utilizando o questionário UKSMEF 2008, e adoptando o método de equações simultâneas, os resultados obtidos mostram que as pequenas e médias empresas (PME) inglesas utilizam as garantias (collateral) como factor de sinalização da sua qualidade creditícia, para obterem menores taxas de juro nos empréstimos contraídos. Estes resultados sugerem que o collateral funciona como um dispositivo para atenuar o problema da selecção adversa no mercado de crédito. Ao distinguir garantias pessoais (personal collateral) das garantias prestadas pela própria empresa (business collateral), os resultados sugerem que as garantias pessoais parecem ser mais eficazes enquanto dispositivo de sinalização de acordo com as teorias da sinalização. Considerando a natureza do relacionamento entre o credor e o mutuário, os resultados mostram um efeito de substituição entre a duração da relação bancária e as garantias a prestar pelo mutuário junto do banco principal (main bank). No entanto, o banco principal cobra aos seus mutuários taxas de juro mais elevadas com 0 objectivo de obter rendibilidades supranormais no médio e longo prazo (bargaining hypothesis).

Palavras-Chave: racionamento de crédito, preço do crédito, garantias, relacionamento bancário, pequenas e médias empresas (PMEs).

Classificação JEL: G20; G21 


\section{Contents}

$\begin{array}{ll}\text { 1. Introduction } & 1\end{array}$

2. Credit rationing and the role of collateral as a solution for informational asymmetry between the borrower and the lender

2.1.Credit rationing: an overview

4

2.2. The jointness of collateral and interest rate in pricing of loans

2.3. The strength of relationship between the borrower and the lender and the pricing of loans

3. Data, Method and Variables 10

3.1.Data

10

3.2. Method 11

3.3. Variables

4. Results

4.1. Descriptive analysis

16

4.2. Empirical results 19

4.3. Robustness tests

5. Concluding Remarks

30

References

Appendix 


\section{List of tables}

Table 1 - Variable definitions

Table 2 - Descriptive statistics

Table 3 - Correlation Matrix

Table 4 - OLS estimation for interest rate premium, logistic estimation for business and personal collateral and exogeneity tests

Table 5 - Validation of instrumental variables

Table 6 - Simultaneous system of equation estimation for: interest rate premium, business collateral and personal collateral

Table 7 - Robustness Test

Appendix A - UK Summary literature of collateral studies 


\section{Introduction}

Microeconomic theories of banking and financial intermediation (e.g., Greenbaum and Thakor 1995) have explained the widespread use of collateral by its function to reduce credit rationing under asymmetric information. Theoretical credit rationing occurs if, in equilibrium, the demand for loans exceeds the supply at the prevailing interest rate (Stiglitz and Weiss 1981). Because the expected banks' return increases non-monotonously when the interest rate increases, banks would prefer rationing credit to opaque firms (usually small and young firms) rather than increasing the interest rate (Stiglitz and Weiss 1981). In such situation, collateral would be an important tool for the bank to mitigate informational asymmetries and thus solve the credit-rationing problem.

Pledging collateral to secure loans is a widespread important feature of the credit acquisition process. Cressy and Toivonen (2001) report that for $85 \%$ of loans collateral has to be provided, in the UK. In the USA, 70\% of loans require collateral pledging (Berger and Udell 1990). In addition, due the consolidation of the banking industry and the introduction of the Basel II Capital Accord, informational opaque firms will have to rely even more on collateral (Inderst and Mueller 2007). The consolidation of financial institutions would result in an increased use of transactions lending technologies (Berger and Frame 2007). Transactionlending technologies rely on a particular type of information, such as financial statement for lending, accounts receivable and inventory for asset-based lending, and credit scores. Therefore, only small and medium sized enterprises (SMEs) that can provide collateral to secure the repayment of the loan receive credit from banks (Berger 2006). The introduction of the Basel II Capital Accord is also expected to increase the importance of collateral for opaque firms. Contrary to the Basel I Capital Accord that treated all corporate lending alike, Basel II prescribes that banks engaging in higher risk lending, need to hold a higher amount of capital to safeguard their solvency and overall economic stability (Von Thadden 2004). Consequently, banks would prefer collateralized loans to reduce the risk of their loan portfolio (Bank for International Settlements 2004).

This growing importance of collateral in bank lending seems to have fuelled the interest in this research topic. Thus credit market research explains the use of collateral as a consequence of adverse selection (Besanko and Thakor 1987a,b; Bester 1985; Chan and Kanatas 1985;), and/or moral hazard (Boot et al. 1991), which problems arise in transactions between borrowers and lenders. The nature of the borrower-lender relationship (Rajan 1992; Sharpe 1990), the level of competition in the credit market (Besanko and Thakor 1987a), and the net cost (benefits) of a thorough screening of borrowers can also explain why some loans are secured whereas other loans are granted without collateral (Manove and Padilla 1999; 
Manove et al. 2001) ${ }^{1}$. However, results of these theoretical and empirical studies on the use of collateral as an informational asymmetry reducing tool are not consistent. For instance, literature has not yet settled as whether collateral signals a riskier or a safe loan or whether the nature of borrower-lender relationship increases or decreases the collateral requirements and/or the cost for obtaining a loan.

These seemingly contradicting results may be explained by research set-up failing to taking in accounting the simultaneity in debt terms; lenders do not determine the interest rate separately from any other loan terms such as collateral. Thus, the analytic framework concerning price-setting behaviour of banks and information availability on SMEs has been underdeveloped. Hence, the aim of this study is to investigate how the use of collateral affects the incentives of borrowers, lenders and the relationship between them. More specifically, the study analyses the following issues. First, the study examines if good borrower may offer collateral to reliably signal their low risk type, in turn of a loan contract with a lower interest rate (adverse selection effect) or riskier borrowers are more likely to be required to provide more collateral (moral hazard effect). Second, the study investigates how borrower-lender relationship affects the debt term contracts. Since the existing theoretical and empirical literature (e.g., Brick and Palia 2007; John et al. 2003) has strongly established that collateral requirements is endogenously determined, the study simultaneously examine the main loan contracts terms being the interest rate and collateral requirements, by using a simultaneous equation modelling. Furthermore, because in the context of SMEs the personal wealth of the owner is frequently used to access bank loans and so cannot be entirely separate from the assets of the business, this study distinguishes from these two types of collateral.

Because the majority of studies on loan collateralization is based on credit files of banks $^{2}$ (e.g., Cressy and Toivanen 2001 - UK; Degryse and Van Cayseele 2000 - Belgian; Hanley 2002 - UK; Hanley and Crook 2005 - UK; Jimenez et al. 2006 - Spain; Lehmann and Neuberger 2001 - Germany) or for U.S. (e.g., Ang. et al. 1995; Avery et al. 1998; Berger and Udell 1990; Brick and Palia 2007), the data set employed by this study is based on the United Kingdom (UK) Survey of Small and Medium-Sized Enterprises (UKSMEF) conducted by the Center for Small and Medium-Sized Enterprises (CSME), Warwick Business School.

The main findings of the study can be summarized as follows. The empirical results show strong evidence for jointness in the terms of lending. The findings suggest that if a financial institution considers pledging collateral necessary the loan is also characterized by higher interest rate. These results support the theories that view collateral as an incentive device to mitigate the moral hazard problem. However, the results also show that high quality borrowers (i.e., borrowers which know ex ant their credit quality but lenders do not know, or do not know exactly) choose a contract with more collateral (business collateral and personal collateral) and lower interest rate, in line with theories that explain collateral as a

\footnotetext{
${ }^{1}$ For an extensive survey of the theoretical literature in the use of collateral see Coco (2000).

${ }^{2}$ See appendix A for an overview of the key findings of the studies focusing on UK.
} 
signal of borrower's credit quality, and thus, as a solution to adverse selection problem in credit markets. Moreover, the results of the variables related to loan characteristics also provide empirical support to the signal hypothesis. Regarding the nature of borrower-lender relationship the findings suggest that relationship lending is substitute to business collateral. This substitution effect is weaker for personal collateral. Furthermore, in line with the bargaining-power hypothesis (Petersen and Rajan 1994), the main bank seems uses explicit loan interest rate as a loss leader to secure long-term rents on relationship businesses.

This study contributes to the literature in several ways. First, by using simultaneous equation modelling approach, this study examines the simultaneous impact of the borrowerlender relationship upon the explicit interest rate and one such on collateral. Taking in accounting the interdependences between these contractual debt term conditions may unravel prior ambiguous results. Second, by distinguish business and personal collateral, this study shows that personal collateral seems to be more effective in acting as a sorting device in line with screening models. As this study discusses subsequently, high quality firms seem to prefer pledge personal collateral. With this strategy the borrower avoids more restrictive usage of business collateral. From the point of view of the lender, personal collateral is more effective in limiting the borrower's risk preferences incentives by enhancing the likelihood that the owner will feel the consequences of any ex post managerial shirking and risk- taking activities personally. Moreover, bonding by personal collateral provided by the borrower avoids more costly monitoring requested by business collateral or covenants (Harris and Raviv 1991).

The structure of the paper is as follows. Section two presents an overview about the role of collateral in mitigating informational asymmetries between the borrower and lender, hence solving credit rationing; then develops empirical hypotheses taking account the principles of jointness in debt terms of lending and the nature of borrower-lender relationship. Section three describes data and variables and explains the empirical method employed by the study. Section four presents and discusses the results and section five concludes. 


\section{Credit rationing and the role of collateral as a solution for informational asymmetry between the borrower and the lender}

\subsection{Credit rationing: an overview}

Bank loans are the most widely used form of SMEs financing (European Commision 2002; World Bank 2004). Although, the exchange relationship between lenders and borrowers often suffers from market imperfections, such as, information asymmetries (Cowling 2010; Craig et al. 2007; Freel 2007; Stiglitz and Weiss 1981, Zambaldi et al. 2011). These information asymmetries occur because the lenders have little and no reliable information about the default risk of the applicants (Besanko and Thakor 1987a). Because SMEs are mainly non listed firms, not followed by analysts and lacking any audited financial statements, they often have difficulties to signal their qualities to financial institutions in order to obtain bank finance (Craig et al. 2007; Freel 2007; Zambaldi et al. 2011). Moreover, these firms are not always willing to release any information since it is a time-consuming (costly) occupation. This dilemma is the so called opacity problem (Berger and Frame 2007).

This information asymmetry between bank and SMEs could be so severe that could lead to credit rationing (Stiglitz and Weiss 1981). The credit rationing is one of the most important examples of market failure in our modern economy (Steijvers and Voordeckers 2009a). It can be defined as the situation where the demand for loans exceeds supply at the prevailing interest rate (Stiglitz and Weiss 1981). The rationing of demand may be achieved in two ways: either borrower does not receive the full amount of credit they have applied for (the so called "type I rationing") or some of the borrowers are simply turned down ("type II rationing"). If there is an excess demand for bank funds it should be expected that banks raise loan price (the interest rate) to equal demand for loans with supply, thus increasing profits. But it is well known that in the normal course of bank lending this do not happen. They do not have an incentive to raise the interest rates when demand exceeds supply. As pointed out by Steijvers and Voordeckers (2009a) the bank-optimal interest rate is the equilibrium interest rate since at any interest rate above the bank-optimal interest, the expected return for the bank increases at a slower rate than the interest rate and will even decrease after a certain interest rate is exceeded. Consequently, some borrowers that will not receive bank credit are willing to pay a higher interest rate. If the bank accepted this higher interest rate this means that higher riskier borrowers are attracted (i.e., the adverse selection effect). It is a consequence of different borrowers having different probabilities of repaying their loan (Craig et al. 2007). In another words, the adverse selection effect means 
that the borrower quality is ex ante undetectable by the lending bank which gives the firm an unfair advantage. Sequentially, banks will not accept the higher interest rate because higher risk lending is not expected to be rewarded with higher return. Furthermore, if banks raise the interest rate, the borrowers will prefer higher riskier projects, which mean that the return of the bank will decrease again. This is the moral hazard effect (Steijvers and Voordeckers 2009a). These arguments suggest even in equilibrium that the demand will not equal the supply and that the banks will prefer to ration credit due to adverse selection and moral hazard problems (Stiglitz and Weiss 1981). Thus, looking at the theoretical models studying the effects of an increase in loan price on the lender's loan portfolio (e.g., Besanko and Thakor 1987a,b; Bester 1985), we conclude that some models only assume that credit terms contracts are specified only in terms of the interest rate or collateral, remain silent on possible interdependences between interest rate and collateral. But as argued by Coco (2000), a convincing theory of debt must consider the role of collateral and possible interdependences between interest rate and collateral.

\subsection{The jointness of collateral and interest rate in pricing of loans}

According to Jensen and Meckling (1976) signalling and monitoring are important ways of dealing with the shareholder-debtholder agency conflict. The adverse selection problem may be solved by use of incentive compatibility contracts written in terms of signals providing crucial information about the quality of different agents (Spence 1973). Hence, for firms wanting to signal their creditworthiness, collateral is more widely used rather than other more costly monitoring tools (e.g., Stulz and Johnson 1981). For instance, include debt covenants into debt contracts limit the behaviour of the borrower and put constraints on the management's decisions (e.g., Smith and Warner 1979). But to completely avoid any incentive effects, these covenants would have to be very detailed and cover all aspects of the firm which is almost impossible. Thus, if the collateral's value is more stable or more objectively ascertainable than the distribution of the returns from the project, the entrepreneur could profitability trade it for better interest rates (Chan and Kanatas 1985).

Thus, when the bank has at its disposal two informative instruments it may want to use them jointly as predicted by screening models (e.g., Besanko and Thakor 1987a, b; Bester $1985,1987)$. These theoretical models show that banks simultaneously choose between collateral requirements and the interest rate to screen investors' riskiness. As a result, it is possible to use different contract terms as a self-selection mechanism to separate borrowers of different risk. Hence collateral is used as signal device of high credit quality in situation of adverse selection in which borrowers known their credit quality but lender do not (Chan and Kanatas 1985). Therefore borrowers with a high probability of default choose a contract with 
a higher interest rate and lower collateral than borrowers with a low default probability. Thus, the first hypothesis states:

H1: High ex-ante quality borrowers (low quality borrowers) choose a contract with more collateral (less collateral) and a lower (higher) interest rate.

On the other hand, if the lenders can observe ex-ante borrower's credit quality (e.g., Boot et al. 1991), but there are information asymmetry after the loan is extended, collateral provides an incentive to mitigate (ex pot) moral hazard due its disciplinary role in the behaviour of the borrower (Bester 1994; Rajan and Winton 1995). Collateral prevents the high-risk firm from switching from a lower to a higher risk project after the loan has been granted (i.e., the problem of asset substitution - Jensen and Meckling 1976) or making less effort to realize the proposed project (Boot et al. 1991). Accordingly, riskier borrowers are requested by lenders to put more collateral whereas low risk borrowers obtain loans without having to pledge collateral (e.g., Berger and Udell 1990). Hence the second hypothesis postulates:

H2: High ex-post risk firms pledge more collateral than low risk borrowers.

Hypothesis one suggest an inverse relation between the collateral and interest rate in function of the private information of the borrower about his creditworthiness. In this context, collateral acts as a mechanism by which the borrower's ex-ante shows his risk preferences. To measure the private information which is only known by the borrower, this study uses a dummy variable, namely credit quality, which is defined based on the borrowers' perception about their financial situation (see section 3.2 variables). Because the data set do not have information related to ex post event default, to signal "good" (low risk) versus high risk borrowers, the study uses the variable size (e.g., Cowling, 1999; Diamond 1989). Because larger firms tend to be more diversified, have an historical performance track record, this study expects that firm size is negatively related with risk and thus loan collateralization. Hence failure declines with size.

According the screening models, by pledging collateral the borrower signals the real value and his belief in the quality of the project to the bank (Besanko and Thakor 1987a,b; Bester 1985; Chan and Kanatas 1985; Chan and Thakor 1987). Consequently, in exchange for collateral, the borrower receives the advantage of a lower interest rate, but incurs the risk of losing collateral when the return of the project turns out to be too low. But if expected payoff of the project is too low, the costs associated with collateral exceed the advantages of a lower interest rate, as a result the (high risk) borrower refuse collateralize the loan.

A firm that receives more debt attains a higher leverage level and so increases the risk of non-payment. As a consequence, it is expected that banks ask for more collateral protection (e.g., Degryse and Van Cayseele 2000). Because pledging collateral involves 
numerous costs that can only be full recovered with large loans through economies of scale, the likelihood of pledging collateral is higher for large loan size compared to shorter loan size. In addition, long term debt gives to the borrower enough opportunities to alter the project in subtle ways or even from low-risk to high-risk projects (Jensen and Meckling 1976). In this situation, pledging of collateral is an effective mechanism for the creditor to ascertain himself of a certain value in the future: a company may not retain its value on a longer term but collateral does most likely retain its value (Mann 1997). Furthermore, since an asset can be pledge once and its evaluation is costly, by asking for collateral the main bank ensures its loan senior to other creditors' claim and creates a barrier-to-entry for other banks. So, it is expected that the loan size and the time to maturity of the loan have a positive impact on the incidence of secured debt.

The third and the fourth hypotheses state:

H3: The loan size is positively related with collateral requirements and negatively related with interest rate.

H4: The maturity of the loan is positively related with collateral requirements and negatively related with interest rate.

Nevertheless, business collateral and personal collateral may have different signalling value in solving the agency problems of debt. Business collateral rearranges the relative priority of liabilities upon bankruptcy without altering the risk exposure of the owners. Hence, business collateral may actually benefit the firm's owners. For instance, John et al. (2003) showed a positive relation between the use of business collateral, firm risk and interest rate. In the context of SMEs, because the personal wealth of the owner-manager is frequently used to access bank loans and cannot be entirely separated from the assets of the business (Ang et al. 1995), personal collateral may be a better instrument to signal the quality of the borrower. The owner of a lower quality firm cannot afford to imitate a high quality firm owner due to the threat of losing the personal assets (Brick and Palia, 2007). Therefore personal collateral is more effective in limiting the borrower's risk preference incentives by enhancing the likelihood that the principal will feel the consequences of any ex post managerial shirking and risk-taking activities personally (Mann 1997). In addition, personal collateral can be seen as a substitute for equity investment by the owner: in case of default, the personal assets could be sold in order to repay the loan. In accordance with Brick and Palia (2007), this study expects that the economic impact of the requirement of pledging personal collateral is greater than pledging business collateral. 


\subsection{The impact of the strength of relationship between the borrower and the lender in pricing of loans}

Since reliable information on SMEs is rare and costly, relationship lending is often considered as the most appropriate lending technique for collecting information on SMEs (e.g., Degryse and Van Cayseele 2000; Zambaldi et al. 2011). Good lending relationships facilitate the information exchange because lenders invest in obtaining information from their clients and borrowers are motivated to disclose information (Boot and Thakor 1994). As time goes by, the entrepreneur establishes a good reputation since the firm values a good reputation, a low-risk project will be preferred to a high-risk project, reducing the probability of repayment difficulties and keeping the value of the reputation asset intact (Diamond 1989). Thus, information gathered over time by bank helps to give a more complete picture of the businesses financial health (Boot 2000).

In the literature the strength of the relationship is measured in several ways. A widespread measure is the length/duration of the relationship with the bank (e.g., Ongena and Smith 2001). A long-term relationship allows the lender to gather more private information of the borrower, for instance about the capacities and the character of the borrower, that is, qualitative data (or soft information) which takes significant time to accumulate and it's not easily observed and shared with other financial institutions (Berger and Udell 2006). The information generated by lender over repeated transactions and over time is also beneficial in terms of reducing the fixed cost of screening and monitoring (Boot and Thakor 1994). Such information also avoids the free-rider problem of monitoring since the bank internalizes the benefits of such investments. Hence, because this close relation between borrower and lender, should facilitate the ex ante screening and ex post monitoring and thus mitigate informational opaqueness, the hypothesis five postulates:

H5: The relationship length is negative related with the demand of collateral requirements.

In addition, scope is also considered a dimension of the relationship lending (e.g., Petersen and Rajan, 1994), defined as the quantity of products and/or services that the borrower shares with the bank (Ongena and Smith 2001). This concentration of products/services not only increases the sources of information for the bank but also allow it to dilute the information collection costs by the various bank services, gaining in economies of scale (Diamond 1989). This intense interaction and exchange of information between both parties reduces information asymmetry, reinforces mutual trust and thus reduces the banks' lending risk to this firm. Hence, it is expected that collateral requirements will decrease with the scope of the relationship (Degryse and Van Cayseele 2000). Accordingly, this study hypothesis: 
H6: The scope of the borrower-lender relationship is negative related with the demand of collateral requirements.

Even though several studies have examined how the relationship lending affects the likelihood of collateral being pledging (e.g., Berger and Udell 1995; Degryse and Van Cayseele 2000), the empirical studies provides conflicting results about the direction and the significance of the effect. Consistent with information on stronger relationship, Berger and Udell (1995) and Harhoff and Körting (1998) find a negative relation between relationship duration and the use of collateral while Menkhoff et al. (2006) reports no significant effect and Degryse and Van Cayseele (2000) found only a weak effect. But others found a positive effect of the housebank status in line with the lock-in hypothesis (Degryse and Van Cayseele 2000; Lehmann and Neuberger 2001).

However, a solid relationship may become detrimental to the borrower if the housebank, defined as the first and sometimes the only lender to a firm (Elsas and Krahnen 1998), exerts its information monopoly by charging high interest rates or requiring more collateral (i.e., hold-up problem) from its ex post superior bargaining power (Sharpe 1990). Since an asset can be pledge only once, and it defines the order of seniority among creditors, initiating a second bank lending relationship is costly because the new lending firm entails switching costs for the borrower; consequently, the firm gets locked-in the relationship (Boot and Thakor 1994). So, in line with the Petersen and Rajan (1994) bargaining hypothesis, which states that lenders subsidize borrowers (especially small and young firms) in early periods to be reimbursed in later periods, the hypothesis seven is as follow:

H7: The relationship length is positively related with the interest rate premium.

Furthermore, because collateralization reduces a bank's risk exposure, it may provide an incentive to the bank to be less careful, or even to engage in a more risky lending (i.e., the lazy bank" argument - Manove et al. 2001). Thus, if an inefficient allocation of resources the benefits that bank losses will be paid by the clients who have maintained their relationships with the hausbank (D’Auria et al. 1999; Lehmann and Neuberger 2001). 


\section{Data, method and variables}

\subsection{Data}

For the empirical analysis this study uses the United Kingdom (UK) Survey of Small and Medium-Sized Enterprises (UKSMEF) conducted by the Center for Small and Medium-Sized Enterprises (CSME), Warwick Business School ${ }^{3}$. The first survey was carried out by CSME in 2004 with funding from a large consortium of public and private organizations led by the Bank of England. The second survey was conducted by the University of Cambridge in 2007. The third survey was conducted in 2008 among 2500 SMEs (corresponding to a population of 4.4 millions of SMEs), defined as firms with less than 250 employees in the private sector in the UK. Public sector and not for profit organizations were excluded, together with the Financial Services, Mining and Quarrying, Electricity, Gas and Water Supply sectors. The sample structure was set in order to allow the analysis by size, sector and government standard regions.

The advantages of this data set are threefold. First, the UKSMEF provides information whether the borrowing firm has pledge business and/or personal collateral to the hausbank (i.e., the main relationship lender). The UKSMEF defines business collateral as an asset to the borrowing firm that will be transferred to the lender in the event of default. Personal collateral/guarantees refers to assets no belonging to the legal entity of the firm but provide by an external party or owner/manager of the firm. In addition, the survey also provides information about the interest rate premium paid by the borrower. Second, the UKSMEF asks for a variety and detail questions regarding the number of years that the borrower and its main bank have been conducting transactions and the list of financial services that the borrower has purchased from its main bank. These variables enable us to analyse how the business and personal collateral and the interest rate premium are related to the closeness of the borrower-lender relationship. Third, the survey also comprises questions related to the firms' perceptions of their riskiness as well the history of past default of the firm and/or the owner. Nevertheless, there are several drawbacks of this data set that should be mentioned. First, the data related to the financial statements are scarce. Second, the questions in the UKSMEF survey are about transactions between a firm and its main bank, but not individual loans contracts. Thus, if a firm has multiple loans contracts with its main bank with different contract terms, the use rates of personal and/or business collateral and the interest rate premium charged may be biased. Third given that the survey does not identify the lender, we cannot match the firm-level data with the financial variables of firm's main bank neither the

\footnotetext{
${ }^{3}$ UK Data Archive Study number 6314 - United Kingdom Survey of Small and Medium-Sized Enterprises Finances, 2008.
} 
lender's Herfindahl Index. So, the study does not control for the lender characteristics. And fourth, the UKSMEF survey (as is the case in the most surveys) deals with surviving firms; despite it does include firms that have previously defaulted. Because this study aims to analyse the price-setting behavior of banks, the data set comprises only firms that demanded for bank credit and reported information related to interest rate premium charged and/or collateral requirements (i.e., business and/or personal collateral). As a result the final sample has 326 SMEs for empirical analysis.

\subsection{Method}

Because lenders do not determine the interest rate separately from any other loan terms such as business and /or personal collateral (e.g., Brick and Palia 2007), this study employs a simultaneous equation method. This method allows to separately estimating the impact of each type of collateral on the loan interest rate premium and on each other.

Furthermore, the existing theoretical and empirical literature (e.g., Berger and Udell 1995; Boot and Thakor 1994; Brick and Palia 2007; Rajan and Winton 1995) has strongly established that the collateral requirement is endogenously determined. The endogeneity problem occurs because the dependent variable (e.g., in Equation 1, interest rate premium) may also cause the explanatory variables (in Equation 1, business and personal collateral) (Steijvers and Voordeckers 2009b). Therefore, dependent variables are also endogenous regressors which are correlated with the regressions errors, and thus, ordinary least squares (OLS) can yield biased estimators. To control for endogeneity problem this study uses an instrumental variables, two-stage least-squares framework (e.g., Brick and Palia 2007). The instrumental variables should be correlated with that equation's endogenous variable, but uncorrelated with the others potential endogenous variables and also uncorrelated with error term. Accordingly the simultaneous system of equations is defines as follow:

$$
\begin{aligned}
\text { Interest rate premium }= & a_{I R P}+B_{I R P} \text { business collateral }+\delta_{I R P} \text { personal collateral } \\
& +\lambda_{I R P} X+\varphi_{I R P} W+\varepsilon_{I R P} \\
\text { Business collateral }= & a_{B C}+B_{B C} \text { interest rate premium }+\delta_{B C} \text { personal collateral } \\
& +\lambda_{B C} X+\varphi_{B C} W+\varepsilon_{B C} \\
\text { Personal collateral }= & a_{P C}+B_{P C} \text { interest rate premium }+\delta_{P C} \text { business collateral } \\
& +\lambda_{P C} X+\varphi_{P C} W+\varepsilon_{P C}
\end{aligned}
$$

For each (potential) endogenous variable, this study employs specific instruments. So, we rely on instrumental variables to measure the independent variables business collateral and personal collateral in equation 1 , interest rate premium and personal collateral in equation 2 
and interest premium rate premium and business collateral in equation 3 . In addition, in the specification, the study differentiates between a vector of independent variables $(X)$ and a vector of control variables (W).

\subsection{Variables}

\section{Dependent endogenous variables}

The dependent variables are interest rate premium (IRP), business collateral (BC) and personal collateral $(\mathrm{PC})$. Interest rate premium is defined as the difference between the contractual interest rate and the prime rate (e.g., Berger and Udell 1995; Brick and Palia 2007). Business collateral (BC) and personal collateral (PC) are dummies variables that take the value 1 if the borrower pledges business collateral or personal collateral/guarantees to its main bank, respectively. Table 1 presents the definition of all the variables.

\section{Independent and control variables}

The independent variables incorporate several firms, loan and borrower-lender relationship characteristics. Firm variables include credit quality $(\mathrm{H} 1)$ and firm size $(\mathrm{H} 2)$. The UKSMEF database allows us to define a binary dummy variable with the value of 1 if the firm shows a low level of financial distress. In the UKSMEF the definition of this variable is somewhat subjective as each respondent firm is asked to define its final situation based on its own perception. So, this study uses this dummy variable, namely credit quality as a proxy for private information, that is, information that the lender does not have or know only imperfectly at the time the loan is granted. To identify "good" (low risk) borrowers, (i.e., observable signals by the bank), the study uses the variable firm size, measured by the natural logarithm of total assets. The bank can use public information to assess the borrower quality such as: Dun and Bradstreet (D\&B) scores (e.g., Cavalluzzo et al. 2002) or the variance of equity returns (e.g., Booth and Booth 2006). The UKSMEF provides the Dun \& Bradstreet credit rating. However, due the high missing values for this variable, it was excluded from the analysis. Because SMEs are not public quoted companies we do not have information related to equity returns.

Loan characteristics include loan size $(\mathrm{H} 3)$ (i.e., natural logarithm of the loan size measured in pounds), the loan maturity $(\mathrm{H} 4)$ (i.e., the natural logarithm of the loan maturity in years), a binary variable (fixed rate) that controls if the loan has a fixed rate (e.g., Brick and Palia 2007), and the fitted values of collateral requirements and interest rate premium resulting from the instrumental variable technique (see instrumental variables section).

As the borrower-lender variables this study includes the relationship length (H5; H7) with the main bank (i.e., the natural logarithm of the number of years the firm has dealt with its main bank) and the variable scope ( $\mathrm{H} 6)$ which indicates the number of financial products the borrower has purchased from the main bank. As for scope, the UKSMEF asks firms to list 
all products/services, other than loans, which they have purchased from their main bank. Then, we tabulate the number of products (and services) for each firm over the total products offered by the main bank.

As control variables, the study controls for the industry and organizational form. Hence, the study includes nine dummy variables to account for industry differences. To capture possible differences in collateral requirements due to liability differences between firms organized as an S-Corporation, C-Corporation, Limited Liability Company or Limited Liability Partnership, four dummy variables were included.

\section{Instrumental variables}

The UKSMEF provides a limited choice of possible instrumental variables. The instrumental variable used in interest rate premium equation is the variable firm delinquency, a dummy variable that is equal to 1 if the firm has previously defaulted, and zero otherwise. The study assume that the likelihood of a lender to impose a higher interest rate should be positively related to whether the firm has defaulted on previous loan [e.g., Han et al. (2009) show that borrowers with a delinquent history pay higher interest rate].

From the point of view of the bank, collect information about small firms is costly. Consequently, banks rely more on the use of collateral requirements, especially fixed assets (such as real estate), because its value is relatively more stable. Furthermore, by taking collateral the bank can guarantee that another lender is aware of the first bank's preference (Boot and Thakor 1994). Hence securing credit limits the firms' ability to obtain future loans from another lender and overleveraged the firm. In addition, pledging business collateral restricts the possibility of the firm to sell the business assets pledged in order to invest the selling value in new project (Smith and Warber 1979) or to use it for perk consumption (John et al. 2003). Thus, for the business collateral equation the instrumental variable employed is the variable fixed assets (e.g., Ono and Uesugi 2009). This variable takes the value one if the loan must be supported by a compensating balance sheet fixed asset, and zero otherwise.

However, as Mann (1997) agues, personal collateral is more effective in limiting the borrower's risk preference incentives because increases the likelihood that the principal will feel any consequences of any ex post managerial shirking and risk-taking activities. Thus, by pledging personal collateral, the owner signals his or her belief in the firm and its ability to repay the loan. So, in personal collateral equation, this study uses the age of the CEO/owner (i.e. the natural logarithm of the CEO/owner age) as instrumental variable. Young borrowers start with scant information in their commercial and financial records, but as time goes by, information accumulates can be used by lenders to update their credit quality (e.g., Diamond 1989). The study follows Bolton (1971), assuming that a small business is owned and managed by the same individual and/or family. For an overview of the all variables definitions, see table1. 
Table 1: Variable definitions

\begin{tabular}{l}
\hline Variable \\
\hline Dependent variables
\end{tabular}

Interest rate premium

Business collateral

Personal collateral

Independent variables

Credit quality

Firm size

Loan size

Loan maturity

Fixed rate

Relationship length

Scope

Control variables

Industry

S-corporation

C-corporation

Limited liability company

Limited liability partnership

Instrumental variables

Firm delinquency

Fixed assets

CEO age
Definition

Difference between the contractual interest rate and the prime rate

Equals 1 if the firm is required to post business collateral; 0 otherwise

Equals 1 if the owner is required to post personal collateral/guarantees; 0 otherwise

Equals 1 if the firm show a low level of financial distress; 0 otherwise

Natural logarithm of firm's total assets

Natural logarithm of the loan size measured in pounds

Natural logarithm of the loan maturity in years

Equals 1 if the loan has a fixed rate; 0 otherwise

Natural logarithm of the relationship length in years with the main bank

Number of financial products the firms has purchased from the main bank

Equals 1 it the firms belongs to industry $x$ (with $x$ varying 1 to 9 to distinguish between 9 industries); 0 otherwise

Equals 1 it he firm is organized as a S-corporation; 0 otherwise

Equals 1 it he firm is organized as a C-corporation; 0 otherwise

Equals 1 it he firm is organized as a limited liability company; 0 otherwise

Equals 1 it he firm is organized as a limited liability partnership; 0 otherwise

Equals 1 if the firms has previously defaulted; 0 otherwise

Equals 1 if the loan must be supported by a compensating balance sheet

assets; 0 otherwise

Natural logarithm of the age of the CEO in years 
The validity of these instruments will be formally tested in the analysis subsequently To implement tests for exogeneity, this study employs the methodology of Rivers and Vuong (1988) and Wooldridge (2002: 474). Accordingly, the study begun with the OLS estimation for the interest rate premium variable and logit estimations for business collateral and personal collateral variables, respectively, assuming that the debt contracts terms are exogenous explanatory variables. For example, regarding the OLS estimation for interest rate premium variable, the business $(\mathrm{BC})$ and personal collateral $(\mathrm{PC})$ variables are assumed to be exogenous. Then, tests for exogeneity are implemented. The procedure is as follows: i) first, the study runs the OLS regression for possible endogenous variables, that is, interest rate premium, business collateral and personal collateral variables, on all independent and control variables, including instrumental variables and we obtain the reduce form residuals, ii) second, the study then runs the OLS regression for interest rate premium and logit regression for business and personal collateral on all exogenous variables (i.e, independent and control variables), including possible endogenous variables and their instruments plus the residuals obtained in the first step. If the t-statistics on these residuals (e.g., the residuals from logit estimations for business and personal collateral variables in the interest rate premium regression) show they are insignificant, then the null hypothesis that the contracts terms are exogenous is not rejected. If one (or both) contracts terms turns out to be endogenous, then the study checks the validity of the instrumental variables by regress the instrumented variable on the instrumental variables. Finally, the fitted values obtained from the previous stage are used as independent variables in the interest rate premium rate equation. The same procedure methodology is used for business collateral equation and personal collateral equation. 


\section{Results}

\subsection{Descriptive analysis}

Table 2 presents the descriptive statistics of the variables used in this study. To conserve space, the statistics for control variables are not report (i.e., nine and four dummy variables for industry and organizational form, respectively). The percentage of firms that pledged business collateral is $35.9 \%$, whereas the percentage of firms that pledged personal collateral is $20.9 \%$. The mean firms pay an interest rate premium of $4.35 \%$. The median value of interest rate premium is 5 . The mean firms have a 1519540 pounds of total assets (i.e., firm size), and $57.7 \%$ (i.e., the mean of credit quality variable) of the firms perceive themselves as low risk borrowers. Table 2 also shows that the relationship length with the main bank is 14.5 years and firms purchase more than $50 \%$ of their financial services from their main bank (the mean value for the variable scope is 55.5\%). Looking at loan characteristics, the mean value of loan size is 546074 pounds with a maturity of 9.6 years, with $39.6 \%$ of the firms had negotiated a fixed rate.

Table 3 reports the correlation matrix. The correlation values for the independent variables are less than 0.5 (Gujarati and Porter 2010), which indicates that multicollinearity was not a problem. Due to uncertainty about the population distribution, the study uses a Spearman correlations coefficient estimation, a non-parametric technique based on ranks rather than the value of variables. 
Table 2: Descriptive statistics

\begin{tabular}{|c|c|c|c|c|c|c|}
\hline & $\mathrm{N}$ & Mean & Median & Standard Deviation & Min. & Max. \\
\hline \multicolumn{7}{|l|}{ Dependent variables } \\
\hline Interest Rate Premium & 326 & 4.350 & 5 & 2.850 & 1 & 12.5 \\
\hline Business Collateral & 326 & 0.359 & 0 & 0.480 & 0 & 1 \\
\hline Personal Collateral & 326 & 0.209 & 0 & 0.407 & 0 & 1 \\
\hline \multicolumn{7}{|l|}{ Independent Variables } \\
\hline Firm size & 326 & $1,519,540$ & 750,000 & $1,644,093.092$ & 10,000 & $5,000,000$ \\
\hline Credit Quality & 326 & 0.577 & 1 & 0.495 & 0 & 1 \\
\hline Loan size & 326 & $546,073.620$ & 750,000 & $354,919.814$ & 2,500 & $1,000,000$ \\
\hline Loan Maturity & 326 & 9.617 & 12.50 & 4.541 & 1 & 15 \\
\hline Fixed rate & 326 & 0.396 & 0 & 0.490 & 0 & 1 \\
\hline Relationship length & 326 & 14.49 & 10.00 & 13.242 & 0 & 82 \\
\hline Scope & 326 & 0.550 & 0.57 & 0.177 & 0.140 & 1 \\
\hline \multicolumn{7}{|l|}{ Instrumental variables } \\
\hline Firm delinquency & 326 & 0.215 & 0 & 0.411 & 0 & 1 \\
\hline Fixed assets & 326 & 0.534 & 1 & 0.500 & 0 & 1 \\
\hline CEO age & 326 & 48.043 & 50.00 & 13.561 & 27 & 75 \\
\hline
\end{tabular}


Table 3: Correlation Matrix

Spearman Correlations

\begin{tabular}{|c|c|c|c|c|c|c|c|c|c|c|c|c|c|c|}
\hline & & 1 & 2 & 3 & 4 & 5 & 6 & 7 & 8 & 9 & 10 & 11 & 12 & 13 \\
\hline Interest rate premium & 1 & 1 & & & & & & & & & & & & \\
\hline Business collateral & 2 & $-0.138^{\pi x}$ & 1 & & & & & & & & & & & \\
\hline Personal collateral & 3 & -0.014 & $-0.242^{n \pi}$ & 1 & & & & & & & & & & \\
\hline Credit quality & 4 & -0.077 & $0.136^{\pi x}$ & -0.003 & 1 & & & & & & & & & \\
\hline Firm size & 5 & $-0.218^{* *}$ & $0.318^{* *}$ & $-0.119^{* * *}$ & $0.093^{* * *}$ & 1 & & & & & & & & \\
\hline Loan size & 6 & $-0.273^{* *}$ & $0.289^{* *}$ & 0.016 & 0.037 & $0.522^{* *}$ & 1 & & & & & & & \\
\hline Loan maturity & 7 & $-0.104^{\pi \times x}$ & $0.195^{\pi x}$ & 0.018 & 0.021 & $0.140^{\pi x}$ & $0.258^{\pi x}$ & 1 & & & & & & \\
\hline Fixed rate & 8 & $0.505^{n \pi}$ & $-0.135^{\pi x}$ & $-0.107^{\pi \times x}$ & -0.056 & $-0.147^{\pi x}$ & $-0.185^{x \times}$ & $-0.185^{\pi x}$ & 1 & & & & & \\
\hline Relationship length & 9 & 0.038 & $0.104^{* * \pi}$ & -0.033 & $0.129^{* * *}$ & $0.183^{* * *}$ & $0.127^{* * * x}$ & -0.003 & -0.063 & 1 & & & & \\
\hline Scope & 10 & -0.008 & 0.070 & -0.021 & -0.020 & $0.192^{* *}$ & $0.128^{* * * x}$ & 0.018 & -0.023 & $0.162^{* *}$ & 1 & & & \\
\hline Firm delinquency & 11 & $0.202^{\mathrm{nx}}$ & -0.080 & 0.007 & $-0.187^{\pi x}$ & $-0.117^{n \times x}$ & $-0.111^{\pi \times \pi}$ & -0.021 & 0.081 & 0.069 & 0.063 & 1 & & \\
\hline Fixed assets & 12 & -0.071 & $0.187^{\pi x}$ & -0.065 & $0.108^{\pi \times x}$ & $0.122^{\pi \times \pi}$ & 0.085 & $0.129^{*}$ & -0.061 & -0.021 & -0.016 & -0.050 & 1 & \\
\hline CEO age & 13 & 0.034 & 0.034 & $0.091^{\pi \times x}$ & 0.091 & $0.130^{\pi \pi}$ & 0.056 & -0.021 & $-0.095^{\pi \times x}$ & $0.257^{\pi x}$ & 0.015 & -0.056 & -0.024 & 1 \\
\hline
\end{tabular}

Notes: ${ }^{* * *}$ Statistically significant at $1 \%$ level; ${ }^{* *}$ statistically significant idem at $5 \%$ level. 


\subsection{Empirical results}

Panel A of Table 4 reports the benchmark estimation (i.e., OLS estimation for interest rate premium variable (IRP), and logistic estimation for business collateral (BC) and personal collateral ( $\mathrm{PC}$ ) variables, respectively), when all the loan contract terms are treated as exogenous variables. Neither of the coefficients of collateral variables (i.e., business collateral and personal collateral) are related with interest rate premium variable (equation 1). In line with Brick and Palia (2007), this result suggests that the explicit price (interest rate premium) and implicit price (collateral) of loans are not jointly determined. Table 4 also shows that the coefficients of the personal collateral (1.734 in equation 2 ) and business collateral (-1.778 in equation 3 ) variables are negative and statistically significant at $1 \%$. This finding indicates that business and personal collateral are substitutes, that is, SMEs can offer business or personal as collateral to get their loans approved.

Panel $\mathrm{B}$ of table 4 reports the exogeneity tests for the dependent endogenous variables: interest rate premium (IRP), business collateral (BC) and personal collateral (PC). The $t$-statistics of residual terms obtained from the first-step for business collateral $(B C)$ and personal collateral (PC) indicate that we can reject the null hypothesis that personal collateral $(\mathrm{PC})$ is exogenous but we cannot reject the null hypothesis that business collateral $(B C)$ is exogenous, for the interest rate premium equation (IRP) (equation 1). For business collateral (equation 2), the t-statistics of the residuals obtain from personal collateral (PC) are statistically significant at $1 \%$ level, thus we can reject the null hypothesis that personal collateral (PC) is exogenous but we cannot reject that interest rate premium (IRP) is exogenous. In equation 3 , estimation for personal collateral, both t-statistics of the residuals obtained in the first-step for interest rate premium (IPR) and business collateral (BC) are statistically significant at $5 \%$ level and $1 \%$ level, respectively. Accordingly, the study can reject the null hypothesis that these variables are exogenous. Next, this study analysis the effects of treating personal and business collateral as determined simultaneously with interest rate premium to test the empirical hypotheses. For comparison purposes, the results obtain from table 4 (i.e., when all loan term contracts treated as exogenous variables) are compared with the results assuming that those terms are jointly determined. To begin, table 5 assesses the validity of the instrumental variables for each equation. This table has six specifications. The first, the third and the fifth specification measure the explanatory power of the instrumental variables alone while the second, the fourth and the sixth specifications incorporated the contribution of the instrumental variables, independent and control variables taken together for interest rate premium, business collateral and personal collateral equations, respectively.

The coefficient of instrumental variable for the interest rate premium variable (i.e., firm delinquency) is positive and statistically significant at $1 \%$ level in the first specification. When the independent and control variables are included in the second specification the results remain unchanged. This result confirms that borrowers with a delinquent history pay a 
higher interest rate (e.g., Han et al. 2009). The third specification shows a positive and statistically relation between fixed assets (the instrumental variable for business collateral equation) and business collateral variables. The results remain unchanged when the independent and control variables are included (fourth specification). This finding is unsurprised because, first fixed assets can work as collateral directly and second, it is much easier to gauge the market value for fixed assets than for example intangible assets. The fifth specification assesses the performance of the instrumental variable - CEO age in the personal collateral equation. The instrument CEO age (0.909) proves to be positive and statistically significant at $10 \%$ level. Hence, for SMEs the availability of collateral may be determined by personal wealth of the borrower, which increases with age of the owner. We also confirmed that the instrumental variable for the variable interest rate premium (firm delinquency) is not correlated with other potential endogenous variables, business collateral and personal collateral variables. The same analysis is conducted for the fixed assets and CEO age, instrumental variables for business collateral and personal collateral variables, respectively. These variables are not correlated with other endogenous variables. See table 3 which reports the spearman correlation matrix 
Table 4. OLS estimation for interest rate premium, logistic estimation for business and personal collateral and exogeneity tests

\begin{tabular}{|c|c|c|c|c|c|c|c|c|c|c|c|c|}
\hline & 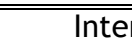 & rest rate & iium (IRP) & & & Business col & teral (BC) & & & ersonal cc & lateral (PC) & \\
\hline & & OLS es & tion & & & Logit est & mation & & & Logit e & imation & \\
\hline & & & T- & & & & & & & & & \\
\hline & Coe & & statistics & & & oeff. & Wald-test & & & eff. & Wald-test & \\
\hline Interest rate premium & & & & & -0.006 & $(0.058)$ & 0.012 & & 0.031 & $(0.063)$ & 0.244 & \\
\hline Business collateral & 0.024 & $(0.312)$ & 0.077 & & & & & & -1.778 & $(0.406)$ & 19.189 & *** \\
\hline Personal collateral & 0.155 & $(0.344)$ & 0.451 & & -1.734 & $(0.419)$ & 17.108 & *** & & & & \\
\hline Credit quality & -0.224 & $(0.278)$ & -0.804 & & 0.571 & $(0.281)$ & 4.135 & ** & 0.144 & $(0.302)$ & 0.226 & \\
\hline Firm size & -0.150 & $(0.084)$ & -1.794 & * & 0.254 & $(0.087)$ & 8.566 & $* * *$ & -0.150 & $(0.091)$ & 2.733 & * \\
\hline Loan size & -0.358 & $(0.121)$ & -2.949 & *** & 0.299 & $(0.139)$ & 4.653 & $* *$ & 0.323 & $(0.151)$ & 4.553 & ** \\
\hline Loan maturity & 0.074 & $(0.210)$ & 0.354 & & 0.699 & $(0.229)$ & 9.310 & $* * *$ & 0.237 & $(0.233)$ & 1.030 & \\
\hline Fixed rate & 2.493 & $(0.284)$ & 8.786 & **** & -0.384 & $(0.328)$ & 1.372 & & -0.636 & $(0.362)$ & 3.085 & * \\
\hline Relationship length & 0.247 & $(0.139)$ & 1.781 & * & 0.131 & $(0.145)$ & 0.817 & & -0.127 & $(0.159)$ & 0.634 & \\
\hline Scope & 0.146 & $(0.774)$ & 0.189 & & -0.631 & $(0.824)$ & 0.586 & & -0.079 & $(0.862)$ & 0.008 & \\
\hline Firm delinquency & 0.864 & $(0.333)$ & 2.595 & *** & & & & & & & & \\
\hline Fixed assets & & & & & 0.525 & $(0.278)$ & 3.559 & * & & & & \\
\hline CEO age & & & & & & & & & 1.318 & $(0.737)$ & 3.198 & * \\
\hline Constant & 8.871 & $(1.461)$ & 6.073 & *** & -9.431 & $(1.865)$ & 25.560 & $* * *$ & -8.306 & $(3.222)$ & 6.644 & $* * *$ \\
\hline Number of observations & & 326 & & & & 326 & & & & 326 & & \\
\hline R-square/Log-Likelihood & & 0.322 & & & & 329.615 & & & & 288.7 & & \\
\hline Panel B: Exogeneity tests & & & & & & & & & & & & \\
\hline resid_Interest rate premium & & & & & $\overline{1.510}$ & $\overline{\nu(1.422)}$ & 1.127 & & -1.986 & $(0.907)$ & $\overline{4.791}$ & $1^{* *}$ \\
\hline resid_Business collateral & 0.745 & $(1.554)$ & 0.479 & & & & & & 39.112 & $(6.847)$ & 32.633 & $3^{* * *}$ \\
\hline resid_Personal collateral & -13.320 & $(2.788)$ & -4.778 & $* * *$ & 329.102 & $(124.817)$ & 6.952 & $* * *$ & & & & \\
\hline
\end{tabular}

Notes: Standard errors are reported in parentheses. This study also controls for industry (nine dummy variables) and organizational form (four dummy variables) but their results are not reported. ${ }^{* *}$ Statistically significant at $1 \%$ level; ** Statistically significant at $5 \% ;{ }^{*}$ Statistically significant at $10 \%$ level. 
Table 5. Validation of instrumental variables

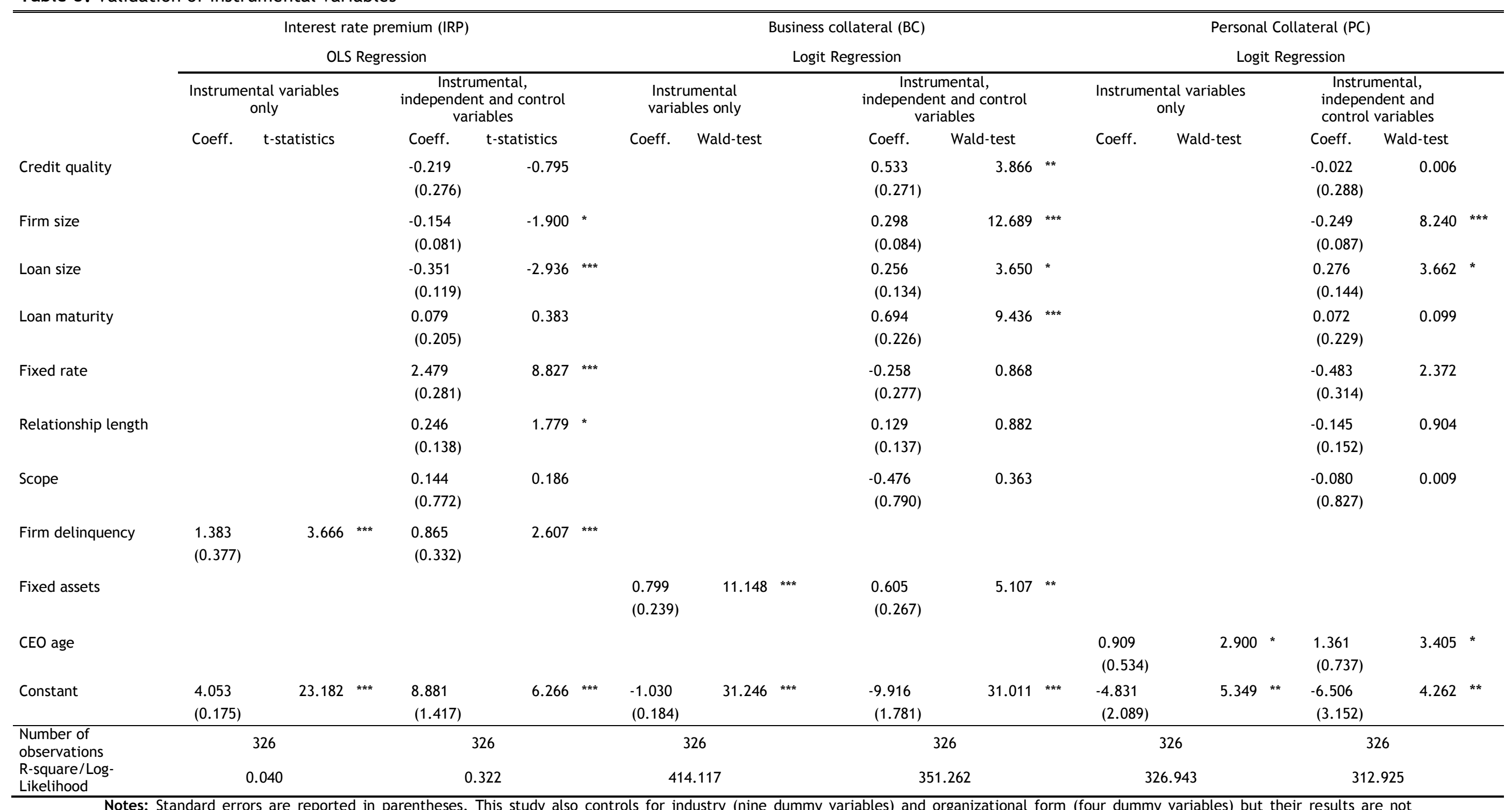

Notes: Standard errors are reported in parentheses. This study also controls for industry (nine dummy variables) and organizational form (four dummy variables) but their results are not reported. ${ }^{* * *}$ Statistically significant at $1 \%$ level; ${ }^{* *}$ statistically significant at $5 \%$ level; ${ }^{*}$ statistically significant at $10 \%$ level 
Table 6 reports the simultaneous system of equations results, based on two-stage least squares (2SLS) estimations. For the interest rate premium regression (equation 1), in the first stage, the study regresses a logistic regression for personal collateral (i.e., the endogenous variable) on all independent, control and instrumental variables. The fitted values from this stage are used as independent variable in the interest rate premium equation on table 6. The same methodology is used for business collateral and personal collateral equation. To identify endogenous variables see Panel B of Table 4.

Table 6 shows that the endogenous variable business collateral as well as personal collateral variable becomes statistically at $1 \%$ level in the interest rate premium equation. Moreover, the positive sign that simultaneous estimation assigns to the variables business and personal collateral suggests that posting collateral controls and implicitly prices (some) of the loss exposure lenders face in risk loans. Recall that in table 4 these variables are not statistically significant. In addition, the results from collateral equations show that the coefficient of the interest rate premium variable is positive and statistically significant at $5 \%$ level, in both collateral equations (1.622 and 2.142 in business and personal collateral equations, respectively). In line with Brick and Palia (2007), these results suggest that debt contracts terms are jointly determined, that is, borrowers who are charged by higher interest rate are more likely to have a collateralized loan. Moreover, in line with results reported on table 4, but in opposition to Brick and Palia (2007), table 6 also shows a significant substitution effect at $1 \%$ level between business and personal collateral. These results could be due the fact that firms may demonstrate their willingness to pledge business collateral but in the case of they are business collateral constrained, as the case of most young and small firms, they can also pledge personal collateral. 
Table 6. Simultaneous system of equation estimation for: interest rate premium, business collateral and personal collateral

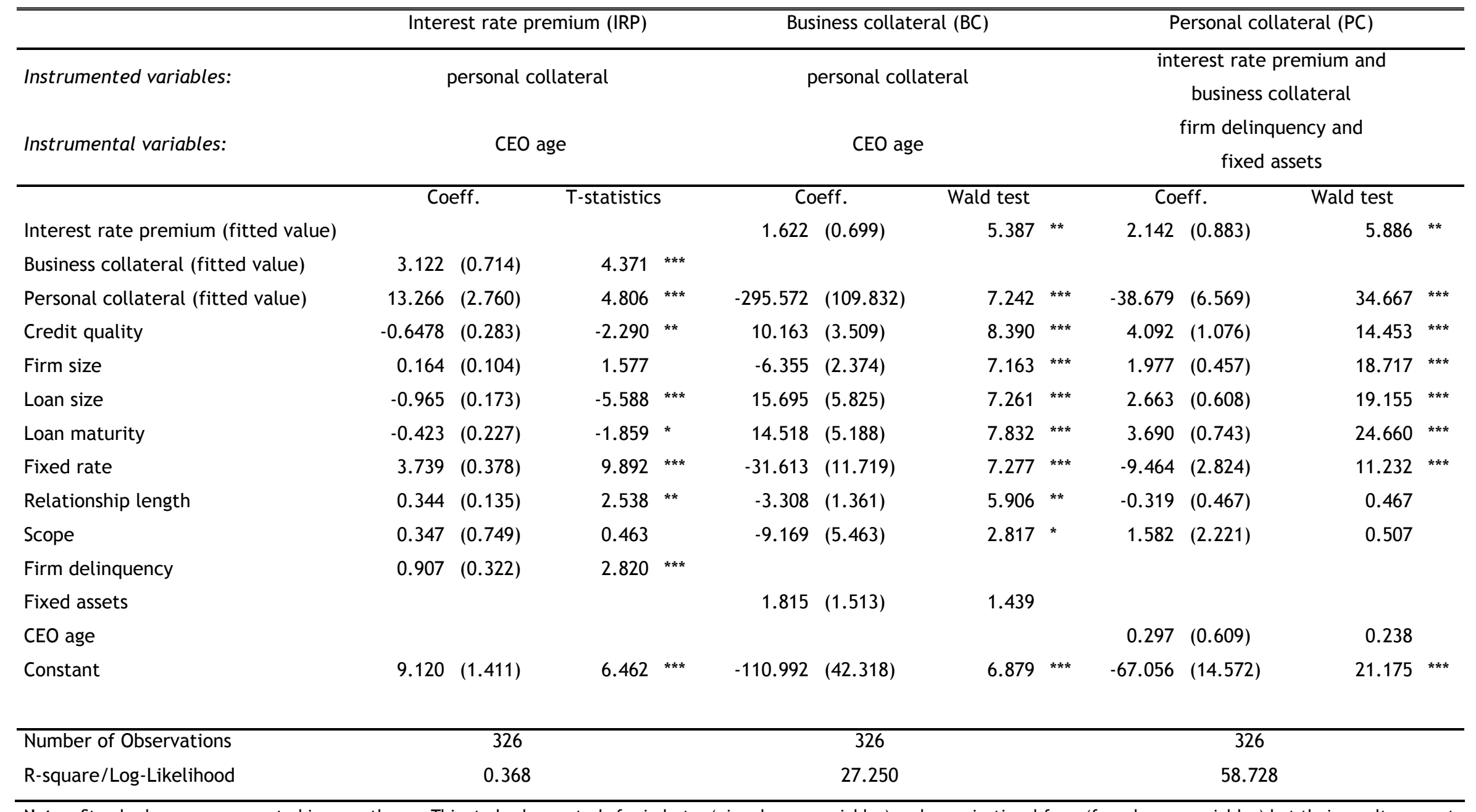

Notes: Standard errors are reported in parentheses. This study also controls for industry (nine dummy variables) and organizational form (four dummy variables) but their results are not reported. ${ }^{* * *}$ Statistically significant at $1 \%$ level; ${ }^{* *}$ statistically significant at $5 \%$ level; ${ }^{*}$ statistically significant at $10 \%$ level. 
Regarding empirical hypothesis, table 6 shows that the coefficient of the variable credit quality (which proxies for private information, and defines the borrower's credit quality known only to the borrower) is positive and statistically significant at $1 \%$ level in both collateral equations (10.163 and 4.092 for business and personal collateral equations, respectively) whereas for the interest rate premium equation the coefficient of this variable is negative $(-0.648$, significant at $5 \%$ level). These results, in line with Jimenez et al. (2006) support the hypothesis one which states that high quality borrower chooses a contract with more collateral (business or personal) to obtain a low interest rate. From table 4 , the benchmark estimation, this variable reports the same sign but it is only positive and statistically significant at $5 \%$ for the business collateral equation.

Regarding the variable size, the proxy for the observable risk by the lender (recall that the study hypothesis that the failure probability declines with size, see for example Cowling 1999), table 6 reports a negative and statistically significant at $1 \%$ level coefficient (6.355 ) in the business collateral equation but a positive coefficient (1.977 significant at $1 \%$ level) in the personal collateral equation. For the interest rate the coefficient is positive (0.164) but not statistically significant. These results differ from table 4 . In table 4 the variable firm size is only statistically significant at $1 \%$ level but with the opposite sign (i.e., positive) in business collateral equation. In the interest rate premium equation and personal collateral equation, the effect of this variable is marginal (statistically significant only at $10 \%$ ), with the opposite sign compared to table 6 . Thus, these results support partially the second hypothesis, which hypothesis that high risk borrower (i.e., small borrowers) are requested by the lender to pledge more collateral. Bad borrowers (i.e., very small firms) knowing they are risky (e.g., Hanley 2002), are very reluctant to post collateral, business or personal collateral against borrowing, as they have a higher probability of losing it. Thus, only good borrowers (i.e., biggest SMEs) will be willing to put more collateral, especially personal collateral, against a loan, as they feel confident that they will not default and loose their assets. Furthermore, good borrowers seem to prefer pledge personal collateral instead of business collateral (e.g., Avery et al. 1998) to reduce the restrictions on business collateral usage, and thus, to be able to employ them in more profitable projects. Therefore, these results suggest that personal collateral is more effective in acting as a sorting device in line with screening models (e.g., Besanko and Thakor 1987a; Bester 1985)

Thereby, the likelihood of collateralization is also determined by the loan characteristics (e.g., Degryse and Van Cayseele 2000; Zambaldi et al, 2011). The results show that loan size is positively related at $1 \%$ level of significance with both types of collateral and negatively related with interest rate premium at $1 \%$ level. The variable loan maturity reports similar results. Furthermore, the results from the benchmark estimation, table 4 , are qualitatively similar, beside the weaker significance of the variable loan maturity in interest rate premium equation and personal collateral equation. Therefore, in accordance with Cressy (1996), these results support the hypothesis three and four, indicating that collateral 
(business and personal collateral) also has implication for the cost of borrowing ${ }^{4}$. Accordingly, borrowers are more likely to pledge collateral to receive a lower interest rate as predicted by the signalling hypothesis (e.g., Bester 1985).

The literature also shows that the loan maturity and loan size could also to be endogenous variables (e.g., Berger et al. 2003). However, because of limitations of data set, it is difficult to find instruments for loan size and loan maturity that would not also be correlated to interest rate premium and collateral variables. As robustness, this study also tests the impact of the independent variables when the variable loan maturity is excluded from each equation. The results of the three loan conditions regression not materially change (results not reported for brevity, but available from the authors upon request).

Regarding the variable relationship length, table 6 shows a negative coefficient (3.308 ), significant at $5 \%$ level, in the business collateral equation, whereas in personal collateral equation, the result is not even statistically significant. For the variable scope, the results also prove to be significant at weaker levels. The results are qualitatively the same as the benchmark estimation (see table 4). Hence, these estimates partially support the hypotheses 5 and 6 , which suggest a substitution effect between relationship length/scope with the main bank and business collateral requirements. These results are in line with Steijvers et al. (2010) which predict that the length of relationship lending decreases the likelihood of pledging any kind of collateral. In addiction according to Han et al. (2009) we can assume that length is an "inverse measure" of the asymmetric information degree. Thus, a longer relationship lending can be seen as adverse selection device substituting the role of collateral. However, a long-term relationship with the main bank seems to have a positive effect on interest rate premium charges by the lender, as the variable relationship length in the interest rate premium equation reports a positive sign statistically significant at $5 \%$ level (0.344). This result is in line with the Petersen and Rajan (1994) bargain hypothesis, which states that, the main bank uses explicit loan inters rate as a loss leader to secure long-term rents on relationship businesses ${ }^{5}$. Moreover, the increase of interest rate premium in the duration of a bank-borrower relationship suggests "that inter-temporal shifting of rents is possible" (e.g., Degryse and Van Cayseele 2000:107).

\footnotetext{
${ }^{4}$ It is also true that large loans are more likely to be collateralized because they benefit of scale economies given fixed costs of monitoring the collateralized assets (e.g., Han et. al., 2009). This feature is consistent with owners who post more collateral can borrowing large amounts. But it may also imply a transaction effect because large loans are riskier.
} ${ }^{5}$ Baas and Schrooten $(2010)$ show that the relationship lending leads to relatively high loan interest
rates compared to other lending technologies, such as, transaction based lending. 


\subsection{Robustness tests}

So far the results provide empirical evidence that borrower uses collateral as a signal device of his high credit quality, unknown to the lender at the time the loan is granted (e.g., table 6 shows that the likelihood of collateralization is mainly determined by the borrower private information and the loan characteristics). Accordingly, there may be no (or even a negative) relation between collateral (business or personal collateral) and interest rate premium. However, the results from table 6 show that the interest rate at which firms borrow is higher for those posting collateral than that those do not, a result that is in contradiction with the signal hypothesis. Because in the UKSMEF survey there is no question related if the bank seeks collateral from the borrower before issuing the most recent loan or if the borrower offers collateral to the bank; and we do not have information about borrowers that default after obtaining the loan, this study can only assess the signalling role of collateral (business and personal collateral) indirectly. Hence, this study adds to interaction variables to verify the main conclusions explained previously. The first interaction variable (INTER1) results from the interaction between borrowers credit quality and young firms. Since information asymmetry is more likely among young borrowers, the use of collateral to signal credit quality should be more frequent among young borrowers than older borrowers (e.g., Jimenez et al. 2006). This study defines young firms, firm which age is below to the first quartile of the age of the firms in the sample, which is 8 years. The second interaction variable (INTER2) aims to control if the main bank charges high interest rates or requires more collateral (hold-up problem) by exerting its ex post bargaining power and thus locked-in the firm in the relationship. The variable INTER2 results from the interaction between the variable relationship length and older firms. As older firms, this study defines firms which age is above the third quartile ( 15 years) of the firms' age sample. The results are reported on table 7.

The coefficient of the variable INTER1 proves to be positive and statistically significant at $1 \%$ level, in personal collateral equation (3.342) while in the interest rate premium equation the coefficient is negative $(-0.627)$ and statistically significant at $5 \%$ level. In business collateral equation, beside positive, the coefficient of the variable INTER 1 (1.385) is not statistically significant. This result could be due because young firms tend to be smaller, and hence, more likely business collateral constrained (e.g., Hanley 2002; Zambaldi et al. 2011). These findings confirm that collateral, especially personal collateral can be used to reveal borrowers types, that is, high quality borrowers signal the real value and their beliefs in the quality of the project to the bank by posting personal collateral, which influences positively the quality of the credit request, as perceives by the bank. Consequently, the bank charges a low interest rate. The owner of a low quality firm cannot afford or imitate the high quality firm owner due the threat of losing personal assets (Brick 
and Palia 2007). In addition, the personal collateral can be seen as a substitute for equity (especially for young firms), because these personal assets could be sold and the proceeds may be then use by the firm to repay the loan.

The results of the variable INTER2 are similar to those in table 6 . The negative coefficient in collateral equation $(-0.246$ and -0.187 in business and personal collateral equations, respectively), confirm that relationship lending is substitute to collateral requirements. Hence, oldest firms with longer relationship lending pledge less collateral (business and personal collateral). These findings are in line with the results reported by Berger and Udell (1995), Brick and Palia (2007) and Jimenez et al. (2006). But the positive coefficient $(0.067$, significant at $10 \%$ level) in the interest rate premium equation still suggests that the main bank uses explicit loan interest rate as a loss leader to secure longterm rents on relationship businesses.

Table 7 also shows that once the study endogenises for collateral use in a simultaneous equation system, the interest rate premium for firms that are required to post collateral is higher than those firms that do not have to post collateral. These results are qualitatively similar to those reports on table 6 . Thus, the positive coefficient on the interest rate variable suggests that borrowers who are charged higher interest rates are more likely to have collateralised loans. In other words, hence if a financial institution considers the pledging collateral is necessary, the loan is also characterized by higher interest rate. This result is in line with John et al. (2003). They demonstrate theoretically that secured public debt has a higher yield than unsecured debt, as a consequence of the agency issues between managers and lenders, due the imperfections in the ratings of the credit agencies. Because reliable information on SMEs is rare and costly for financial intermediaries, the asymmetric information between borrowers and lender is much higher for SMEs. Hence it is expected that interest rate premium of collateral loans should be higher than non-collateral loans (e.g., Brick and Palia 2007). Recall that we do not direct evidence of whether collateral is sought or offered. 
Table 7. Robustness Test

Simultaneous system of equation estimation for: interest rate premium, business collateral and personal collateral with age firm

\begin{tabular}{|c|c|c|c|c|c|c|c|c|c|c|c|c|}
\hline \multirow{3}{*}{$\begin{array}{l}\text { Instrumented variables: } \\
\text { Instrumental variables: }\end{array}$} & \multicolumn{4}{|c|}{ Interest rate premium (IRP) } & \multicolumn{4}{|c|}{ Business collateral (BC) } & \multicolumn{4}{|c|}{ Personal collateral (PC) } \\
\hline & \multicolumn{4}{|c|}{ CEO age } & \multicolumn{3}{|c|}{ CEO age } & & \multicolumn{4}{|c|}{$\begin{array}{l}\text { interest rate premium and } \\
\text { business collateral } \\
\text { firm delinquency and } \\
\text { fixed assets }\end{array}$} \\
\hline & \multicolumn{2}{|c|}{ Coeff. } & \multicolumn{2}{|l|}{ T-statistics } & \multicolumn{2}{|c|}{ Coeff. } & \multicolumn{2}{|l|}{ Wald-test } & \multicolumn{2}{|c|}{ Coeff. } & \multirow{2}{*}{$\begin{array}{r}\text { Wald-test } \\
7.672\end{array}$} & \multirow[b]{2}{*}{$* * *$} \\
\hline Interest Rate Premium (fitted value) & & & & & 0.272 & $(0.175)$ & 2.409 & & 2.919 & $(1.054)$ & & \\
\hline Business Collateral (fitted value) & 2.631 & $(0.672)$ & 3.914 & $* * *$ & & & & & -47.839 & $(9.420)$ & 25.789 & $* * *$ \\
\hline Personal Collateral (fitted value) & 11.347 & $(2.619)$ & 4.333 & $* * *$ & -45.998 & $(12.033)$ & 14.612 & $* * *$ & & & & \\
\hline INTER1 (Credit Quality* Young firms) & -0.627 & $(0.260)$ & -2.410 & ** & 1.385 & $(1.483)$ & 0.872 & & 3.342 & $(1.198)$ & 7.789 & *** \\
\hline Firm Size & 0.086 & $(0.099)$ & 0.863 & & -0.838 & $(0.339)$ & 6.125 & $* *$ & 2.820 & $(0.680)$ & 17.185 & $* * *$ \\
\hline Loan Size & -0.906 & $(0.168)$ & -5.400 & $* * *$ & 2.747 & $(0.782)$ & 12.346 & $* * *$ & 3.537 & $(0.823)$ & 18.453 & $* * *$ \\
\hline Loan Maturity & -0.286 & $(0.223)$ & -1.283 & $* *$ & 3.130 & $(0.883)$ & 12.576 & $* * *$ & 4.236 & $(0.917)$ & 21.342 & $* * *$ \\
\hline Fixed Rate & 3.601 & $(0.371)$ & 9.711 & $* * *$ & -5.701 & $(1.643)$ & 12.031 & $* * *$ & -12.790 & $(3.704)$ & 11.921 & $* * *$ \\
\hline \multicolumn{13}{|l|}{ Relationship length } \\
\hline INTER2 (Relationship Length* Older firms) & 0.067 & $(0.038)$ & 1.775 & * & -0.246 & $(0.120)$ & 14.201 & $* *$ & -0.187 & $(0.125)$ & 2.248 & \\
\hline Scope & 0.540 & $(0.742)$ & 0.728 & & -2.424 & $(2.556)$ & 0.899 & & 1.552 & $(2.418)$ & 0.412 & \\
\hline Firm Delinquency & 0.893 & $(0.320)$ & 2.793 & $* * *$ & & & & & & & & \\
\hline Fixed Assets & & & & & 0.534 & $(0.750)$ & 0.507 & & & & & \\
\hline CEO age & & & & & & & & & 0.394 & $(0.641)$ & 0.378 & \\
\hline Constant & 9.915 & $(1.421)$ & 6.979 & $* * *$ & -22.044 & (7.417) & 8.833 & $* * *$ & -88.627 & $(20.050)$ & 19.540 & $* * *$ \\
\hline Number Observations & & 326 & & & & 326 & & & & 326 & & \\
\hline R-square/Log-likelihood & & 0.370 & & & & 57.959 & & & & 50.691 & & \\
\hline
\end{tabular}

Notes: Standard errors are reported in parentheses. This study also controls for industry (nine dummy variables) and organizational form (four dummy variables) but their results are not reported. ${ }^{* * *}$ Statistically significant at $1 \%$ level; ${ }^{* *}$ statistically significant at $5 \%$ level; ${ }^{*}$ statistically significant at $10 \%$ level 


\section{Concluding Remarks}

This study investigates how the use of collateral affects the incentives of borrowers, lenders and the relationship between them in loan pricing. Specifically, the study analyses if good borrower may offer collateral to reliably signal their low risk type, in turn of a loan contract with a lower interest rate (adverse lection effect) or riskier borrowers are more likely to be required to provide more collateral (moral hazard effect). In addition, the study also examines how borrower-lender relationship affects the debt term contracts.

Using the UKSMEF 2008, the results from a simultaneous equation approach show that debt terms contracts are jointly determined. Borrowers who are charged a higher interest rate pay are more likely to have a collateralized loan. These findings support the theories that view collateral as an incentive device to moral hazard. Nevertheless, the results also indicate that high quality borrowers (i.e., borrowers which know ex ante their credit quality but lenders do not know, or do not know exactly) choose a contract with more collateral (business collateral and personal collateral) to obtain a lower interest rate, suggesting that collateral acts as an incentive device to adverse selection problem in credit markets, according the signal theory. Moreover, by distinguish business and personal collateral, this study suggests that personal collateral seems to be more effective in acting as a sorting device in line with screening models. Good borrowers (i.e., oldest SMEs) seem to be willing to put more collateral, especially personal collateral, against a loan, as they feel confident that they will not default and loose their assets. This strategy allows the borrower to avoid more restrictive usage of business collateral. From the point of view of the lender, personal collateral is more effective in limiting the borrower's risk preferences incentives by enhancing the likelihood that the owner will feel the consequences of any ex post managerial shirking and risk- taking activities personally. In addition, bonding by personal collateral provided by the borrower avoids more costly monitoring requested by business collateral or covenants (e.g., Harris and Raviv 1991). Furthermore, the loan characteristics have implications on the cost of borrowing, that is, borrowers are more likely to pledge collateral to receive a lower interest rate and borrowing a large amount with long maturities as predicted by the signalling hypothesis. Regarding the nature borrower-lender relationship the results show a substitution effect between relationship length with the main bank and collateral requirements. However, a long-term relationship with the main bank seems to have a positive effect on interest rate premium charges by the lender, in line with the Petersen and Rajan (1994) bargain hypothesis. Accordingly, the increase of interest rate premium in the duration of a bank-borrower relationship suggests "that inter-temporal shifting of rents is possible" (e.g., Degryse and Van Cayseele 2000:107). 
However, this study is not without limitations. First, because the data provides only information if the loan is or not collateralizes (binary variable); hence, the study does not control for the scale of the collateral provided. This is any important limitation of the study according Hanley (2002). Second, this study only assesses the signaling role of collateral indirectly due the fact that the study does not have direct evidence of whether collateral is sought or offered. Third, the results also show that the strength of the borrower-lender relationship translates to an increase in the interest rate charged but show a substitution effect with collateral. Thus, it is necessary to evaluate whether the enhanced of bargaining power of the borrower is due to hold-up of the borrower or a strategy to mitigate the soft budget constrain, and thus increases the availability of credit to SMEs. Fourthly, because there is ample empirical evidence that the loan market is highly segmented (e.g., Lambrecht 2009), it is important to control for market conditions. These issues should be addressed in future studies. 


\section{References}

Ang, J., Lin, J., Tyler, F. (1995). "Evidence on the lack of separation between business and personal risks among small businesses”. Journal of Small Business Finance, 4, 197-210.

Avery, R., Bostic, R., Samolyk, K. (1998). "The role of personal wealth in small business finance." Journal of Banking and Finance 22(6-8), 1019-1061.

Bank for International Settlements Basel II: International Convergence of Capital Measurement and Capital Standards: A revised Framework. Basel:BIS. 2004.

Baas, T. and Schrooten, M., (2007). "Relationship banking and SMEs: a theoretical analysis." Small Business Economics 27, 127-137.

Berger, A., (2006). "Potential competitive effects of basel II on banks in SME credit markets in the United States." Journal of Financial Services Research, 29(1), 5-36.

Berger, A. and Frame, W.S., (2007). "Small business credit scoring and credit availability". Journal of Small Business Management 45(1), 5-22.

Berger, A. and Udell, G., (1990)." Collateral, loan quality, and bank risk". Journal of Monetary Economics 25, 21-42.

Berger, A. and Udell, G., (1995)."Relationship lending and lines of credit in small firm finance". Journal of Business 68(5), 351-380.

Berger, A. and Udell, G., (2006). "A more complete conceptual framework for SME finance". Journal of Banking and Finance 30, 2945-2966.

Berger, A., Rosen, R.J., Udell, G., (2003). "Does market size structure affect competition? The case of small business lending". Unpublished manuscript. Board of Governors of the Federal Reserve System, Washington, DC.

Besanko, D. and Thakor, A., (1987a). "Collateral and rationing: sorting equilibria in monopolistic and competitive credit markets." International Economic Review 28, 671-689.

Besanko, D. and Thakor, A., (1987b). "Competitive equilibria in the credit market under asymmetric information." Journal of Economic Theory 42, 167-182. 
Bester, H., (1985). "Screening vs. rationing in credit markets with imperfect information." The American Economic Review 75(4), 850-85.

Bester, H., (1987). "The role of collateral in credit market with imperfect information." European Economic Review 31, 887-899.

Bester, H., (1994). "The role of collateral in a model of debt renegotiation." Journal of Money Credit and Banking, 26(1), 72-86.

Boot, A., (2000). "Relationship banking: what do we know?" Journal of Financial Intermediation 9, 7-25.

Boot, A.., and Thakor, A. (1994). "Moral hazard and secured lending in an infinitely repeated credit market game." International Economic Review 35, 899-920.

Boot, A, Thakor, A., Udell, G. (1991). "Secured lending and default risk: equilibrium analysis, policy implications and empirical results." Economic Journal 101, 458-472.

Booth, J. and Booth, L., (2006). "Loan collateral decisions and corporate borrowing costs". Journal of Money, Credit and Banking 38(1), 67-90. (HAN ET AL, 2009)

Bolton, J., (1971). "Report of the Committee of Enquiry on Small Firms". Cmnd 4811 (London, HMSO). (HAN ET AL, 2009)

Brick, I. and Palia, D. (2007). "Evidence of jointness in the terms of relationship lending." Journal of Financial Intermediation 16, 452-476.

Cavalluzzo, K., Cavalluzo, L., Wolken, J., (2002). "Competition, small business finance, and discrimination: evidence from new survey". Journal of Business 75(4), 641-679.

Chan, Y. and Kanatas, G., (1985). "Asymmetric valuation and the role of collateral in loan agreements". Journal of Money, Credit and Banking 17, 85-95.

Coco, G., (2000). “On the use of collateral." Journal of Economic Surveys, 14(2), 191-214.

Cowling. M., (1999). "The incidence of loan collateralization in small business lending contracts: evidence from the UK". Applied Economics Letters 6, 291- 293. 
Cowling. M., (2010). "The role of loan guarantee schemes in alleviating credit rationing in the UK." Journal of Financial Stability 6, 36-44.

Craig, B., Jackson III, W., Thomson, J., (2007). "Small firm finance, credit rationing, and impact of SBA-guaranteed lending on local economic growth." Journal of Small Business Management 45(1), 116-132.

Cressy, R., (1996). "Commitment lending under asymmetric information: theory and tests on UK data." Journal of Small Business Economics 8, 397-408.

Cressy, R., and Toivanen, O., (2001). "Is there adverse selection in the credit market?" Venture Capital 3(3), 215- 238.

D'Auria, C.,Foglia, A., Reedtz, P., (1999). "Bank interest rates and credit relationships in Italy." Journal of Banking and Finance 23, 1067-109.

Degryse, H. and Van Cayseele, P., (2000). "Relationship lending within a bank-based system: evidence from european small business data." Journal of Financial Intermediation 9, 90-109.

Diamond, D., (1989). "Reputation acquisition in debt markets" Journal of Political Economy 97(4), 828-862.

Elsas, R., and Krahnen, J. (1998). "Is relationship lending special? Evidence from credit-file data in Germany". Journal of Banking and Finance, 22, 1283-1316.

European Commission, (2002). "Highlights from the 2002 survey", Observatory of European SME, 8.

Freel, M., (2007). “Are small innovators credit rationed?” Small Business Economics 28(1), 23-35.

Gujarati, D., and Porter, D., (2010). Essentials of econometrics, $4^{\text {th }}$ ed. New York: McGrawHill International.

Greenbaum, S., and Thakor, A., (1995). “Contemporary financial intermediation”. Dryden Press, Fort Worth, TX.

Han, L., Fraser, S., Storey, D., (2009). "The role of collateral in entrepreneurial finance." Journal of Business Finance and Accounting 36(3\&4), 424-455. 
Hanley, A., (2002). "Do binary collateral outcome variables proxy collateral levels? The case of collateral from start-ups and existing SMEs." Journal of Small Business Economics 18, 317331.

Hanley, A., and Crook, J., (2005) "The role of private knowledge in reducing the information wedge: a research note." Journal of Business Finance and Accounting 32(1\&2), 415-433.

Harhoff, D, and Korting, T., (1998) "Lending relationships in Germany empirical evidence from survey data." Journal of Banking and Finance 22, 1317-53.

Harris, M., and Raviv, A. (1991). "The theory of capital structure". Journal of Finance, 46(1), 297-355.

Inderst, R., and Mueller, H., (2007). "A lender-based theory of collateral”. Journal of financial economics 84, pp. 826-859.

Jensen, M., and Meckling, W., (1976). "Theory of the firm: managerial behavior, agency costs and ownership structure”. Journal of Financial Economics, 3, 305-360.

Jimenez, G., Salas, V., Saurina, J, (2006). “Determinants of collateral”. Journal of financial Economics, 81, 255-281.

John, K., Lynch, A., Puri, M., (2003). "Cedit ratings, collateral and loan characteristics: Implications for yield." Journal of Business 76(3), 371-409.

Lambrecht B. M. (2009). "Discussion of thew rtole of collateral in entrepreneurial finance". Journal of Business Finance \& Accouting,36 (3):456-460

Lehmann, E., and Neuberger, D., (2001). "Do relationship matter? Evidence from bank survey data in Germany." Journal of Economic Behavior and Organization 45, 339-359.

Mann, R., (1997). "The role of secured credit in small-business lending". Georgetown Law Journal 86(1), 1-44.

Manove, M. and Padilla, A., (1999). "Banking (conservatively) with optimists". RAND Journal of Economics 30, 324-350.

Manove, M., Padilla, A., Pagano, M., (2001). "Collateral versus project screening: a model of lazy banks." RAND Journal of Economics 32, 726-744. 
Menkhoff, L. Neuberger, D., Suwanaporn, C., (2006). "Collateral -based lending in emerging markets: evidence from Thailand.” Journal of Banking \& Finance 30, 1-21.

Ongena, S., and Smith, D., (2001). "Empirical evidence of duration of relationships." Journal of finance Economics 61(3), 549-575.

Ono, A. and Uesugi, I. (2009). "Role of collateral and personal guarantees in relationship lending: evidence from Japan's SME loan market". Journal of Money, Credit and Banking, 41(5), 935- 960.

Petersen, M., and Rajan, R., (1994). "The benefits of lending relationships: evidence from Small Business data." Journal of Finance (49)1, 3-37.

Rajan, R., (1992). “Insiders and outsiders: the choice between informed and arm's-length debt." Journal of Finance 47, 1367-1399.

Rajan, R. and, Winton, A., (1995). "Covenants and collateral as incentives to monitor." Journal of Finance 50, 1113-1146.

Rivers, D., and Vuong, Q., (1988) "Limited information estimators and exogeneity tests for simultaneous probit models." Journal of Econometrics 39, 347-66.

Sharpe, S., (1990). "Asymmetric information, bank lending, and implicit contracts: a stylized model of customer relationships". Journal of Finance 45, 1069-1087.

Smith, C. and Warner, J., (1979). "On financial contracting: an analysis of bond covenants." Journal of Financial Economics, 7(2), 117-162.

Spence, A., (1973). “Job market signaling.” Quartertly Journal of Economics 87(3), 355-374.

Steijvers, T. and Voordeckers, W., (2009 a). "Collateral and credit rationing: a review of recent empirical studies as a guide for future research", Journal of Economic Surveys, 23(5), 924-946.

Steijvers, T. and Voordeckers, W., (2009 b)."Private family ownership and the agency costs of debt”. Family business Review.

Steijvers, T., Voordeckers, W., Vanhoof, K., (2010). "Collateral, relationship lending and family firms." Small Business Economics 34, pp. 243-259. 
Stiglitz, J., and Weiss, A., (1981). "Credit rationing in markets with imperfect information." The American Economic Review 71(3), 393-410.

Stulz, R, and Johnson, H., (1981). "An analysis of secured debt". Journal of Financial Economics 14, 501-521.

Von Thadden, E., (2004). "Bank capital adequacy regulation under the new Basel Accord." Journal of Financial Intermediation 13(2), 90-95.

Wooldridge, J., (2002). "Econometric analysis of cross section and panel data." Cambridge, MA: The MIT Press.

World Bank (2004). "Review of small business activities." Washington, DC: World Bank Group.

Zambaldi, F., Aranha, F., Lopes, H. Politi R.(2011) “Credit granting to small firms: A Brazilian case”. Journal of Business Research 2011;64: 309-315. 
Appendix A: UK Summary literature of collateral studies

\begin{tabular}{|c|c|c|c|c|c|}
\hline Paper & Data set & Method & Incidence of collateral (\%) & $\begin{array}{c}\text { Type and size of } \\
\text { the loan }\end{array}$ & Main findings \\
\hline 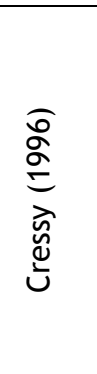 & $\begin{array}{l}\text { Data set provided by a } \\
\text { questionnaire applied to the } \\
\text { business start-ups which opening } \\
\text { business accounts at the } \\
\text { National Westminster Bank of } \\
\text { Great Britain (1988). }\end{array}$ & $\begin{array}{l}\text { Ordinary Least Squares } \\
\text { (OLS) and Logit Maximum } \\
\text { Likelihood estimates (two } \\
\text { stage least squares - 2SLS) } \\
\text { with Overdraft margins and } \\
\text { Security as dependent } \\
\text { variables. }\end{array}$ & $\begin{array}{l}\text { About } 80 \% \text { of start-ups are not } \\
\text { secured by "Manager or Head Office } \\
\text { Secured Limit". }\end{array}$ & $\begin{array}{l}\text { Overdraft. } \\
\text { Minimum limit is } \\
£ 50 \text { and the } \\
\text { maximum } \\
£ 150,000 \text {. }\end{array}$ & $\begin{array}{l}\text { Overdraft margins are positive related to } \\
\text { probability of default (PD) and negative } \\
\text { related to security. Security increase with } \\
\text { loan size and decrease with PD. Inversely, } \\
\text { margins decrease with loan size. Thus, } \\
\text { security is important input as monitoring } \\
\text { device solving moral hazard. }\end{array}$ \\
\hline 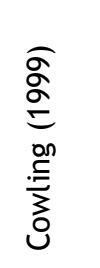 & $\begin{array}{l}\text { Data set provided by Association } \\
\text { of British Chambers of } \\
\text { Commerce Survey (1991). }\end{array}$ & $\begin{array}{l}\text { Logit regression with the } \\
\text { collateralization decision } \\
\text { (dummy) as dependent } \\
\text { variable. }\end{array}$ & $\begin{array}{l}40.3 \% \text { of loans are secured by } \\
\text { business collateral, } 16.7 \% \text { by } \\
\text { personal collateral and } 22 \% \text { of cases } \\
\text { are secured by a combination of } \\
\text { business and personal collateral. }\end{array}$ & $\begin{array}{l}\text { Commercial and } \\
\text { Industrial Loan. } \\
\text { Loan size at } £ 8,000 \\
\text { as maximum. }\end{array}$ & $\begin{array}{l}\text { Collateralization increase with loan size } \\
\text { and loan maturity and decrease with firm } \\
\text { age. Lending provided by a local bank } \\
\text { increase the likelihood of pledging } \\
\text { collateral. }\end{array}$ \\
\hline 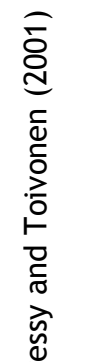 & $\begin{array}{l}\text { Data set provided by a major U.K } \\
\text { bank. Individual loans over 1987- } \\
1990 .\end{array}$ & $\begin{array}{l}\text { Two stage least squares } \\
\text { (2SLS) to estimate } \\
\text { simultaneously collateral, } \\
\text { interest rate and loan } \\
\text { amount as dependent } \\
\text { variables }\end{array}$ & $62 \%$ of loans are collateralized. & $\begin{array}{l}\text { Commercial Loans. } \\
\text { The average loan } \\
\text { is } € 19,000 \text {. }\end{array}$ & $\begin{array}{l}\text { Loan duration seems increasing collateral } \\
\text { pledge. Relationship lending does not } \\
\text { have any significant effect in collateral. } \\
\text { Furthermore, better borrowers get larger } \\
\text { loans at lower rates }\end{array}$ \\
\hline
\end{tabular}




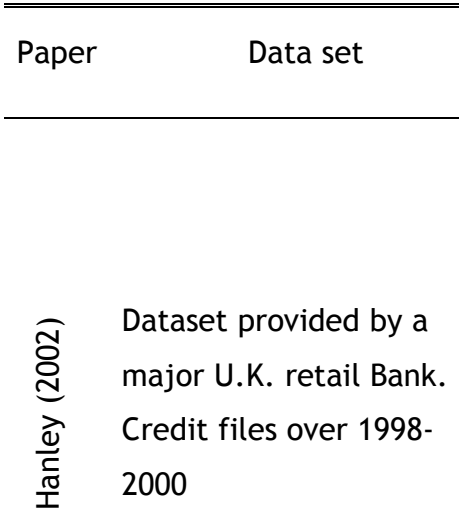

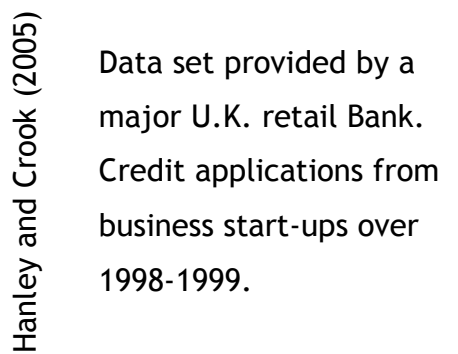

\section{Logit regression for}

binary collateralization

decision. Tobit

regression for

collateralization (\%).
For Transfer Start-Up Group (TS) firms above the median of leverage ratio represent $48.3 \%$ of sample collateralization, in the first semester of 1999 and $53.6 \%$ in the second semester of the same year. To Existing Businesses group (EB) firms above the median of leverage ratio represents $53.3 \%$ of sample collateralization, in the first semester of 1999 and $43.3 \%$ in the second semester of the same year.
Overdrafts and

Commercial Loans. Only include firms which borrowed at least $£ 1,000$. Maximum amount is $€ 100,000$.
Logit regression with $\quad$ Firms with extended credit provide $88 \%$ of commercial loan rejection as dependent variable. collateral given the loan amount requested.

Firms with denied credit have some $69 \%$ of collateralization.
Business credit. Firms which managed to secure bank finance were more likely to request smaller amounts (about $\mathrm{f67,000)}$ than unsuccessful borrowers $(£ 77,000)$.
The two estimation methods used produce similar results. EB firms need to hold more collateral than TS firms. Loan size increases the probability to pledge collateral. The likelihood of collateral requirements also increases if the firm aims to buy fixed assets.

\section{Increasing the amount of} collateral available and reducing the amount of finance requested increases the likelihood that loan will be granted by the firm. Lender who has previously relationships with borrower has a greater incentive to extend credit. 
Appendix A: UK Summary literature of collateral studies (continuation)

\begin{tabular}{|c|c|c|c|c|c|}
\hline Paper & Data set & Method & Incidence of collateral (\%) & $\begin{array}{l}\text { Type and size of the } \\
\text { loan }\end{array}$ & Main findings \\
\hline & Dataset from UK Small & & & & \\
\hline & Firms Loan Guarantee & Probit regression with, & & & \\
\hline 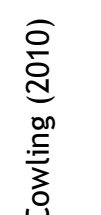 & $\begin{array}{l}\text { Scheme. Information } \\
\text { about } 35 \text { Banks, collated } \\
\text { centrally by the } \\
\text { Department of Business }\end{array}$ & $\begin{array}{l}\text { Collateral and Floating } \\
\text { rate as dependent } \\
\text { variable for the credit } \\
\text { rationing behaviour }\end{array}$ & $\begin{array}{l}30.43 \% \text { of the loans involve the posting of } \\
\text { collateral by the borrower. }\end{array}$ & Loan Guarantee Scheme & $\begin{array}{l}\text { The paper reports that collateral } \\
\text { is positive associated with higher } \\
\text { risk borrowers and information } \\
\text { problems. }\end{array}$ \\
\hline
\end{tabular}

Enterprise and Regulatory study.

Reform (1993-1998). 